\title{
MERISTIC AND BIOMETRIC PARAMETERS OF SPINED LOACH, COBITIS TAENIA (L.) (CYPRINIFORMES, COBITIDAE) FROM ZEGRZYŃSKI DAM RESERVOIR
}

\author{
CECHY MERYSTYCZNE I BIOMETRYCZNE KOZY, COBITIS \\ TAENIA (L.) (CYPRINIFORMES, COBITIDAE) Z ZEGRZYŃSKIEGO \\ ZBIORNIKA ZAPOROWEGO
}

Department of Zoology, University of Agriculture and Technology, Olsztyn, Poland

The paper presents the results of studies on meristic and biometric parameters in spined loach, Cobitis taenia $(\mathrm{L}$.) from Zegrzyński Dam Reservoir. Body proportions were determined as well as the relations between the parameters under study and body and head length. Statistically significant differences were found in the values of some biometric parameters in males and females. The results were compared with the data from the literature of spined loach populations in which the species Cobitis taenia was well defined.

\section{INTRODUCTION}

Spined loach, Cobitis taenia Linnaeus, 1758, is a representative of the Cypriniformes order, suprafamily Catostomoidea, family Cobitididae, subfamily Cobitidinae (Nelson 1984). Range of its distribution is rather large, extending over almost all Eurasia, northward to $60^{\circ}$ latitude.

Recent studies proved that also other Cobitis species occur within this range, such as Cobitis elongata Heck, Cobitis biwae Jord. et Snyder, and other (Vasileva 1984, 1988; Vasilev et al. 1989, 1990). There are a lot of discrepancies caused by the lack of detailed studies on morphologic parameters of Cobitis representatives in different areas of occurrence.

This study was suported by Olsztyn University of Agriculture and Technology, grant number 5040805 . 
Spined loach, Cobitis taenia, is characterized by considerable variability of plastic parameters', so that many subspecies appear. In Japan there is Cobitis taenia striata (Ueno and Ojima 1976; Sezaki et al. 1985), in Korea there is C. taenia lutheri (Kim and Jeong 1987, 1988). In north and central Italy C. taenia bilineata and C. taenia puta are very popular (Lodi 1979, 1980; Marconato and Rasotto 1989).

Due to high morphologic variability of spined loach and the possibility that a number of subspecies coexist, morphologic parameters of various fish subspecies were described and mixed up in earlier studies (Vasileva 1984, 1988). Cobitis granoei Rendahl was described by Gladicov as Cobitis taenia sibirica (Osinov et al. 1983; Vasileva 1984, 1988; Vasilev et al. 1989, 1990).

In polish literature there are very few papers on spined loach. Morphologic parameters in this fish from the Biebrza River were described by Witkowski (1984) and from the Wschodnia River by Skóra (1966). Spined loach from lakes Legińskie and Dgał Wielki was described by Białokoz (19.86).

Analysis of meristic and biometric parameters of spined loach from Zegrzyński Dam Reservoir was the aim of the present study. Attention was given to the differences in body proportion between males and females. The results were compared with the data from the literature.

\section{MATERTAL AND METHODS}

Analyses of morphologic parameters were based on 80 females (body length 39.0 $-76.9 \mathrm{~mm}$ ) and 60 males (body length 38.8-73.0 mm) caught in Zegrzyński Dam Reservoir. The fish were caught in nearshore lake zone, with a fry tow net of mesh size $5 \mathrm{~mm}$ and wing $15 \mathrm{~m}$. Each samples was preserved in $4 \%$ formalin.

23 parameters were measured for each fish according to the method given by Pravdin (1931). The measurements were made up to $0.1 \mathrm{~mm}$. The parameters were selected taking into account also the works by other authors (Rolik 1960; Vasileva 1984; Witkowski 1984; Frankiewicz 1985) on spined loach (Tab. 1). Length of the jaw bristle $\left(\mathrm{x}_{9}\right)$ refers to the length of the longest bristle protruding from the fish mouth.

Body proportions were determined using percentage coefficients of biomeric parameters (Pravdin 1931). Values of $x_{2}, x_{3}$ and from $x_{12}$ to $x_{26}$ were presented as percentages of body length. Values of the parameters related to head $\left(x_{4}-x_{9}\right)$ were presented as percentages of head length. Significance of the differences in mean values between females and males were determined with Student's $t$ test, verifying the hypothesis on the equality of these means $\left(\mathrm{H}_{0}: \mathrm{m}_{1}=\mathrm{m}_{2}\right)$ at 0.05 significance level (Zuk 1989). 
Table 1

Biometric parameters

\begin{tabular}{|l|l|l|}
\hline \multicolumn{2}{|c|}{ Parameter } & \multicolumn{1}{c|}{ Latin name } \\
\hline $\mathrm{X}_{1}$ & body length & longitudo corporis \\
$\mathrm{X}_{2}$ & total length & longitudo totalis \\
$\mathrm{X}_{3}$ & head length & longitudo capitis lateralis \\
$\mathrm{X}_{4}$ & preeye distance & spatium praeorbitale \\
$\mathrm{X}_{5}$ & eye diameter & diameter oculi \\
$\mathrm{X}_{6}$ & posteye distance & spatium postorbitale \\
$\mathrm{X}_{7}$ & head height & altitudo capitis \\
$\mathrm{X}_{8}$ & intereyes distance & distantia interorbitale \\
$\mathrm{X}_{9}$ & bristle length & longitudo cirri \\
$\mathrm{X}_{12}$ & predorsal length & distantia praedorsale \\
$\mathrm{X}_{13}$ & postdorsal length & distantia postdorsale \\
$\mathrm{X}_{14}$ & greatest body height & altitudo corporis maxima \\
$\mathrm{X}_{16}$ & preanal distance & longitudo praeanalis \\
$\mathrm{X}_{17}$ & smallest body height & altitudo corporis minima \\
$\mathrm{X}_{18}$ & caudal length & longitudo pedunculi caudae \\
$\mathrm{X}_{19}$ & dorsal fin length & longitudo $\mathrm{D}$ \\
$\mathrm{X}_{20}$ & dorsal fin height & altitudo $\mathrm{D}$ \\
$\mathrm{X}_{21}$ & anal fin length & longitudo $\mathrm{A}$ \\
$\mathrm{X}_{22}$ & anal fin height & altitudo $\mathrm{A}$ \\
$\mathrm{X}_{23}$ & pectoral fin length & longitudo $\mathrm{P}$ \\
$\mathrm{X}_{24}$ & ventral fin length & longitudo V \\
$\mathrm{X}_{25}$ & P - V distance & distantia $\mathrm{P}-\mathrm{V}$ \\
$\mathrm{X}_{26}$ & V - A distance & distantia $\mathrm{V}-\mathrm{A}$ \\
\hline
\end{tabular}

Absolute values were used to calculate correlation coefficients and linear regression to determine the relationships between the elements under study with body and head length. Linear regression formula $y=a+b x$ was used, where $y-$ parameter under study, $x-$ body or head length, $b$ - regression coefficient, $a$ - free equation factor.

In order to determine the differences between the sexes Snedecor's F statistics was used, verifying the hypothesis $\left(\mathrm{H}_{0}: \mathrm{b}_{1}=\mathrm{b}_{2}\right)$ on the equality of linear regression coefficients, at significance level of 0.05 . In cases when $\mathrm{H}_{0}$ hypothesis was accepted, i.e. when the two tested lines were parallel, the same statistics was used to test the free equation factors (a). The hypothesis in this case was: $\mathrm{H}_{0}: \mathrm{a}_{1}=\mathrm{a}_{2}$. In the case of statistically significant differences, the regression equations were given separately for females and males.

To determine the relationships between the parameters under study and body head length, the hypothesis was verified that the free factor of the equation equalled zero $\left(\mathrm{H}_{0}: \mathrm{a}=0\right)$ using Student's $t$ test at the significance level 0.05 .

The following were counted to characterize the meristic parameters: number of soft rays in the fins ( $D, A, C, P, V)$, number of gill rakers on the first gill arc (sp. branch.), vertebrae number (vt. from $x$-ray pictures, the four vertebrae forming Weber's apparatus inclusive), number of spots on the dorsal part (in front of the dorsal fin - $n$. macul. praed, and behind this fin - n. macul. postD), and number of large spots on body sides (n. macul. 
lateralis.). The results were presented as range of values, arithmetic means, standard deviations and coefficients of variability.

To compare the results with the literature data the hypothesis $\mathrm{H}_{0}$ on the equality of the mean values $\left(\mathrm{m}_{1}=\mathrm{m}_{2}\right)$ was verified whenever possible, using the Student's $t$ test.

\section{RESULTS}

\section{Colouring}

Spined loach is cream-yellow, with numerous dark spots on the dorsal and lateral parts of the body. The head is strongly pigmented. Ventral part light yellow. Caudal and dorsal fins covered with a few rows of regular dark spots. Spots at body sides from three rows. The first row is composed of large, oval or rectangular spots, their upper edges laying at the lateral line or slightly above it. Number of these spots ranged between 11 and 20. Most fish (65.0\%) had 14-16 spots (Tab. 2). Upwards, above the lateral line, there is a narrow belt of small, round spots running along the fish body. The third row is above the second one. It is composed of smaller spots and dots which merge with each other.

The dorsal part, from the head to the caudal fin, is covered with large, dark-brown spots. Their number amounted to 18.3 on the average, but this feature was characterized by high variability ( $\mathrm{V}=15.23)$. Most fish $(65.0 \%)$ had 9 to 10 spots in front of the dorsal fin, and 8 to 10 behind it (75.5\% of the fish) (Tab. 2). One elongated black spot was located at the base of the caudal fin, upon its dorsal part. The mouth is surrounded by lips - the lower one is divided into lobes which can be still divided into another ones. The first two pairs of bristles grow out from the upper lip, the third and the longest one from mouth corners. Dark brown coloured belt runs obliquely from the first pair of the bristles, through the eye to the head end. Double spine, sometimes covered with skin, is located under the eye.

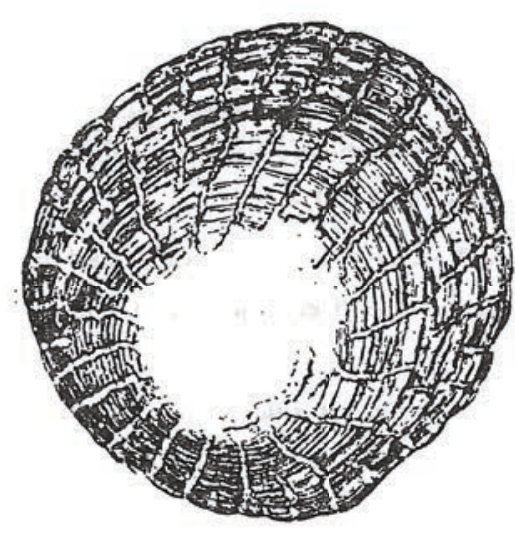

Fig. 1. Scale of spined loach. Magn. $60 \times$
Scale cover, sex dimorphism

Spined loach body is covered with small scales, overlapping each other, with no central area (Fig. 1).

One-year old males can be well distinguished from females as they possess Canestrini's organ (Lodi 1980). It is a bony structure in form of an oval blade, growing at the base of the second ray of the pectoral fin. Male pectoral fin is shaped differently than the female one because its second ray is longer than other rays. In females the longest ray is the third one, so their pectoral fins have different shape. 
Values of meristic parameters of spined loach

Table 2

\begin{tabular}{|c|c|c|c|c|c|c|c|c|c|c|c|c|c|c|c|c|c|c|c|c|c|c|c|c|c|c|}
\hline \multirow{2}{*}{$\begin{array}{l}\text { Para- } \\
\text { meter }\end{array}$} & \multicolumn{22}{|c|}{ Number of fish with this value } & \multirow[b]{2}{*}{$\mathrm{n}$} & \multirow[b]{2}{*}{$\bar{x}$} & \multirow[b]{2}{*}{ S.D. } & \multirow[b]{2}{*}{ V\% } \\
\hline & 4 & 6 & 7 & 8 & 9 & 10 & 11 & 12 & 13 & 14 & 15 & 16 & 17 & 18 & 19 & 20 & 40 & 41 & 42 & 43 & 44 & 45 & & & & \\
\hline $\bar{D}$ & & 55 & 79 & 2 & & & & & & & & & & & & & & & & & & & 130 & 6.58 & 0.5644 & 8.58 \\
\hline A & 712 & 8 & & & & & & & & & & & & & & & & & & & & & 135 & 5.01 & 0.3402 & 6.78 \\
\hline $\mathrm{C}$ & & & & & & & & & & & & 123 & 7 & & & & & & & & & & 139 & 16.00 & 0.3503 & 2.19 \\
\hline$P$ & 3 & 66 & 41 & 2 & & & & & & & & & & & & & & & & & & & 135 & 6.11 & 0.7488 & 12.26 \\
\hline V & 5 & 82 & 5 & & & & & & & & & & & & & & & & & & & & 139 & 5.66 & 0.5458 & 9.64 \\
\hline $\begin{array}{l}\text { sp. } \\
\text { branch. }\end{array}$ & & & & & 3 & 10 & 55 & 54 & 16 & & & & & & & & & & & & & & 138 & 11.51 & 0.8733 & 7.59 \\
\hline vt. & & & & & & & & & & & & & & & & & 2 & 7 & 36 & 37 & 36 & 13 & 131 & 43.05 & 1.1389 & 2.92 \\
\hline $\begin{array}{l}\text { n.macul. } \\
\text { lateral. }\end{array}$ & & & & & & & 4 & 6 & 18 & 34 & 31 & 26 & 13 & 4 & 2 & 1 & & & & & & & 139 & 14.81 & 1.6806 & 11.35 \\
\hline $\begin{array}{l}\text { n.macul. } \\
\text { praeD }\end{array}$ & & & 9 & 17 & 38 & 52 & 12 & 4 & 2 & 2 & 2 & & & & & & & & & & & & 138 & 9.60 & 1.4626 & 15.23 \\
\hline $\begin{array}{l}\text { n.macul. } \\
\text { postD }\end{array}$ & & 3 & 22 & 42 & 32 & 31 & 9 & & & & & & & & & & & & & & & & 139 & 8.67 & 1.2300 & 14.19 \\
\hline
\end{tabular}


Meristic parameters.

Spined loach had 2 or 3 hard rays in the dorsal fin and 6 or 7 soft ones, these numbers being found in $39.6 \%$ and $56.8 \%$ of the fish (Tab. 2). All fish had 2 hard rays in the caudal fin, and between these two $88.5 \%$ of the fish had 14 soft rays (Table 2 showns hard and soft rays in the caudal fin together). This parameter was characterized by the lowest variability ( $\mathrm{V}=2.19 \%$ ). There were 2 or 3 hard rays in the anal fin, and $89.2 \%$ of the fish had 5 soft rays in this fin.

One hard ray in the ventral fish had $93.5 \%$ of the fish. Number of soft rays was characterized by high variability ( $\mathrm{V}=9.64 \%) ; 37.4 \%$ and $59.0 \%$ of the fish had 5 or 6 soft rays respectively.

So regards number of soft rays in the fins, the highest coefficient of variability was found in the case of pectoral fins ( $\mathrm{V}=12.26 \%$ ). In $21.6,47.9$ and $29.5 \%$ of the fish there were respectively 5, 6 and 7 soft rays in this fin. The most of the fish $(97.1 \%)$ had one hard ray in pectoral fins (Tab. 2).

The first branchial arc usually had 11 and 12 gill rakers (39.6 and $38.8 \%$ of the fish respectively). Other fish had 9,10 or 13 gill rakers (Tab. 2).
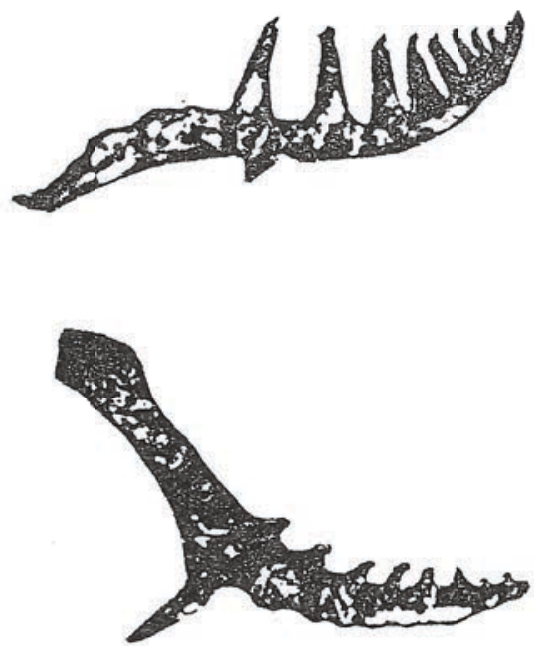

Fig. 2. Pharyngeal teeth of spined loach. Magn. 20×

Spined loach has one row pharyngeal teeth (Fig. 2). In $31 \%$ of the fish their pattern was $11: 11$, in $16.1 \%$ was $10: 11$, in $13.8 \%$ 9:10 and in $14.9 \%$ 10:10. Other fish were characterized by different patterns: 10:8, 8:10 and even 13:13. Upper part of arc is concave, occuping low position. Lateral part with a blunt processus. Upper end slightly forked, while the lower one bent upwards.

\section{Biometric parameters}

The relationships between body measures and body length $\left(\mathrm{x}_{1}\right)$, and between head measures and head length $\left(\mathrm{x}_{3}\right)$ were statistically significant when absolute values were in the calculations. Correlation coefficients were positive and significant at the level 0.05 , and their values ranged from 0.5892 to 0.9807 (Tab. 3). 
Table 3

Correlation coefficients $(r)$ and linear regression equation $(y=a+b x)$ for the relationships between plastic body parameters $\left(\mathrm{x}_{2}, \mathrm{x}_{3}, \mathrm{x}_{12}-\mathrm{x}_{26}\right)$ and body length ( $\left.\mathrm{x} 1\right)$, and between plastic head parameters $\left(\mathrm{x}_{4}-\mathrm{x}_{9}\right)$ and head length $\left(\mathrm{x}_{3}\right)$

\begin{tabular}{|c|c|c|c|c|c|}
\hline Parameter & Sex & Regression equation & $\mathrm{H}_{0}: \mathrm{a}=0$ & $\mathrm{r}$ & Range* \\
\hline \multicolumn{6}{|c|}{$y=a+b x_{1}$} \\
\hline$x_{2}$ & $\mathrm{~F}, \mathrm{M}$ & $y=5.0836+1.0653 x_{1}$ & $\mathrm{P}<0.05$ & 0.9771 & $119.6-113.1$ \\
\hline $\mathrm{x}_{3}$ & $\mathrm{~F}, \mathrm{M}$ & $y=2.1015+0.1587 x_{1}$ & $\mathrm{P}<0.05$ & 0.9367 & $21.4-18.6$ \\
\hline $\mathrm{x}_{12}$ & $\mathrm{~F}, \mathrm{M}$ & $y=1.9821+0.4838 x_{1}$ & $\mathbf{P}<0.05$ & 0.9666 & $53.6-51.1$ \\
\hline$x_{13}$ & $\mathrm{~F}, \mathrm{M}$ & $y=-1.9611+0.4302 x_{1}$ & $\mathrm{P}<0.05$ & 0.9640 & $37.9-40.4$ \\
\hline \multirow[t]{2}{*}{$\mathrm{x}_{14}$} & F & $y=-2.4343+0.1771 x_{1}$ & $P<0.05$ & 0.9424 & $11.6-14.6$ \\
\hline & $M$ & $y=-1.1734+0.1622 x_{1}$ & $P>0.05$ & 0.8885 & $13.1-14.6$ \\
\hline $\mathrm{x}_{16}$ & $\mathrm{~F}, \mathrm{M}$ & $y=1.5660+0.7547 x_{1}$ & $\mathrm{P}<0.05$ & 0.9807 & $79.5-77.7$ \\
\hline \multirow[t]{2}{*}{$\mathrm{x}_{17}$} & $\mathrm{~F}$ & $y=-1.2341+0.1074 x_{1}$ & $\mathrm{P}<0.05$ & 0.9399 & $7.6-9.1$ \\
\hline & $\mathrm{M}$ & $y=0.4252+0.0838 x_{1}$ & $P>0.05$ & 0.8602 & $8.5-8.9$ \\
\hline $\mathrm{x}_{18}$ & $\mathrm{~F}, \mathrm{M}$ & $y=-0.0434+0.1516 x_{1}$ & $P>0.05$ & 0.8809 & $14.9-15.1$ \\
\hline$x_{19}$ & $\mathrm{~F}, \mathrm{M}$ & $y=0.7412+0.0901 x_{1}$ & $P>0.05$ & 0.8169 & $10.9-10.0$ \\
\hline \multirow[t]{2}{*}{$\mathrm{x}_{20}$} & $\mathrm{~F}$ & $y=2.1592+0.1172 x_{1}$ & $P<0.05$ & 0.8436 & $17.2-14.6$ \\
\hline & M & $y=0.4098+0.1581 x_{1}$ & $P>0.05$ & 0.8688 & $16.8-16.3$ \\
\hline $\mathrm{x}_{21}$ & $\mathrm{~F}, \mathrm{M}$ & $y=0.6010+0.0689 x_{1}$ & $\mathrm{P}>0.05$ & 0.7948 & $8.5-7.7$ \\
\hline \multirow[t]{2}{*}{$\mathrm{x}_{22}$} & $\mathrm{~F}$ & $\mathrm{y}=1.0202+0.0953 \mathrm{x}_{1}$ & $\mathrm{P}>0.05$ & 0.8437 & $12.2-11.8$ \\
\hline & M & $y=-0.0359+0.1223 x_{1}$ & $P>0.05$ & 0.8058 & $12.1-12.2$ \\
\hline \multirow[t]{2}{*}{$\mathrm{x}_{23}$} & $\mathrm{~F}$ & $y=0.7446+0.1201 x_{1}$ & $P>0.05$ & 0.8820 & $13.9-13.0$ \\
\hline & M & $y=-1.1664+0.1842 x_{1}$ & $\mathrm{P}>0.05$ & 0.7892 & $15.5-16.8$ \\
\hline \multirow[t]{2}{*}{$\mathrm{x}_{24}$} & F & $y=1.3088+0.1038 x_{1}$ & $\mathrm{P}<0.05$ & 0.8763 & $13.7-12.1$ \\
\hline & M & $y=0.7116+0.1206 x_{1}$ & $\mathrm{P}>0.05$ & 0.8530 & $13.9-13.0$ \\
\hline$x_{25}$ & $\mathrm{~F}, \mathrm{M}$ & $y=-0.6748+0.3269 x_{1}$ & $P>0.05$ & 0.8748 & 30.9-31.8 \\
\hline $\mathrm{x}_{26}$ & $\mathrm{~F}, \mathrm{M}$ & $y=-0.7055+0.2817 x_{1}$ & $P>0.05$ & 0.9171 & $26.3-27.3$ \\
\hline \multicolumn{6}{|c|}{$y=a+b x_{3}$} \\
\hline$x_{4}$ & $\mathrm{~F}, \mathrm{M}$ & $y=-0.4414+0.4043 x_{3}$ & $\mathrm{P}>0.05$ & 0.8908 & $35.0-37.2$ \\
\hline $\mathrm{X}_{5}$ & $\mathrm{~F}, \mathrm{MI}$ & $y=0.3758+0.1442 x_{3}$ & $\mathrm{P}<0.05$ & 0.7284 & $19.0-17.0$ \\
\hline $\mathrm{x}_{6}$ & $\mathrm{~F}, \mathrm{M}$ & $y=0.2123+0.4671 x_{3}$ & $P>0.05$ & 0.9125 & $49.3-48.3$ \\
\hline$x_{7}$ & $\mathrm{~F}, \mathrm{M}$ & $y=-2.6458+0.8264 x_{3}$ & $\mathrm{P}<0.05$ & 0.9227 & $50.4-64.0$ \\
\hline $\mathrm{x}_{8}$ & $\mathrm{~F}, \mathrm{M}$ & $y=0.3036+0.1470 x_{3}$ & $\mathrm{P}>0.05$ & 0.5892 & 18.4-16.8 \\
\hline$x_{9}$ & $\mathrm{~F}, \mathrm{M}$ & $y=-0.0996+0.1211 x_{3}$ & $P>0.05$ & 0.6037 & $10.9-11.4$ \\
\hline
\end{tabular}

* Rangers were calculated taking extreme values of body and head length and calculating the respective parameters for males $(M)$ and fermales $(F)$ from the regression equations. The results are given as percents of body and head length.

Spined loach females differed significantly from males with respect to six parameters. Hence, parameters common for the two sexes shall be discussed first.

Five parameters increased proportionally to females and males bodies length: length of the caudal part $\left(\mathrm{x}_{18}\right)$, length of dorsal and anal fin $\left(\mathrm{x}_{19}, \mathrm{x}_{21}\right), \mathrm{P}-\mathrm{V}$ distance $\left(\mathrm{x}_{25}\right)$ and $\mathrm{V}-\mathrm{A}$ distance $\left(\mathrm{x}_{26}\right)$. Character of these relationships was determined by the free factor in the regression equations, which did not differ signimicantly from zero at 0.05 level ( $\mathrm{P}>0.05)$. Relative values of these parameters did not change with the fish size.

Other parameters related to fish size similarly in males and females did not increase evenly with the fish length. Their relative values differed in fish of different size (,a" factors 
in the equations differed significantly from zero, $P<0.05$. Postdorsal length $\left(x_{13}\right)$ increased more rapidly than body length both in males and females. Smaller fish were characterized by lower relative value of this parameters than the bigger ones (Tab. 3). Head length $\left(x_{3}\right)$, predorsal length $\left(\mathrm{x}_{12}\right)$, preanal distance $\left(\mathrm{x}_{16}\right)$ increased less rapidly than body length (positive „a"). Relative values of these parameters were higher in smaller fish.

No differences were observed between the sexes as regards head measurements. Preeye $\left(x_{4}\right)$ and posteye distance $\left(x_{6}\right)$, distance between the eyes $\left(x_{8}\right)$ and bristle length $\left(x_{9}\right)$ increased proportionally to head length. Character of this increase was determined by the „a" factor which did not differ from zero $(\mathrm{P}>0.05)$.

Other parameters related to head did not increase proportionally to the head length. Factor ,a" was either positive or negative, significantly different from zero $(\mathrm{P}<0.05)($ Tab. 3). Eye diameter $\left(\mathrm{x}_{5}\right)$ increased less rapidly than head length, but the differences between small and big fish were less than $1.0 \%$ so it was assumed that this parameter increased proportionally to head length. Head height $\left(\mathrm{x}_{7}\right)$ increased more rapidly than its length. Relative values of this parameters were lower in small fish than in big ones. Head height was most strongly related to head length, the correlation coefficient between the two being $r=0.9227$ (Tab. 3).

Statistically significant differences of linear correlation coefficients were found between males and females with respect to the greatest body height $\left(\mathrm{x}_{14}\right)$, the smallest body height $\left(x_{17}\right)$, height of $\mathrm{D}$ and $\mathrm{A}$ fins $\left(\mathrm{x}_{20}, \mathrm{x}_{22}\right)$, length of $\mathrm{P}$ and $\mathrm{V}$ fins $\left(\mathrm{x}_{23}, \mathrm{x}_{24}\right)$. Height of anal and pectoral fin $\left(\mathrm{x}_{22}, \mathrm{x}_{22}\right)$ increased proportionally to body length in the females (,a" factors did not differ from zero at 0.05 significance level). The same was true of the length of ventral fins; the difference between small and big fish amounted to $1.6 \%$ only (Tab. 3). The greatest $\left(\mathrm{x}_{14}\right)$ and the smallest $\left(\mathrm{x}_{17}\right)$ body height increased more rapidly than body length of the famales. Relative values of these parameters were lower in smaller fish and higher in bigger ones $6, a$ " factor negave). Height of dorsal fin $\left(\mathrm{x}_{20}\right)$ and length of ventral fin $\left(\mathrm{x}_{24}\right)$ in females increased less rapidly than body length. Free factors in the regression equations describing these relationships were positive and significant. Relative values of these parameters were higher in small fish than in big ones.

All the above parameters, different in males and females, increased proportionally to body length in the case of males (,a" factors did not differ from zero, $\mathrm{P}>0.05$ ). Relative values of these parameters were the same in small and big fish.

Relative values of biometric parameters in spined loach are given in Tab. 4. Statistically significant differences between mean percentages of these parameters in females and males were confirmed with the Student's $t$ test. At the same body length, spined loach males were characterized by higher body, longer pectoral and ventral fins, higher dorsal and anal fins than females. The greatest and smallest body height increased with the age of females, pectoral fins became shorter, and height of dorsal fin decreased. Along with growth, postdorsal 
length increased in both males and females, while predorsal and preanal lengths decreased and head became shorter.

Table 4

Relative values of biometric parameters in spined loach

\begin{tabular}{|c|c|c|c|c|c|c|c|c|}
\hline \multirow{2}{*}{$\begin{array}{l}\text { Para- } \\
\text { meter }\end{array}$} & \multicolumn{4}{|c|}{ Females ( 80 indiv.) } & \multicolumn{4}{|c|}{ Males (60 indiv.) } \\
\hline & Range & Mean & S.D. & V\% & Range & Mean & S.D. & $\mathrm{V} \%$ \\
\hline $\mathrm{x}_{1}$ & $39.5-76.9$ & 63.50 & 4.3771 & 10.28 & $38.8-73.0$ & 52.4 & 6.4578 & 12.32 \\
\hline \multicolumn{9}{|c|}{ in $\%$ of body length } \\
\hline $\mathrm{x}_{2}$ & $87.8-122.3$ & 115.49 & 3.5951 & 3.11 & $111.7-119.8$ & 116.39 & 1.4652 & 1.26 \\
\hline $\mathrm{x}_{3}$ & $16.0-21.5$ & 19.47 & 1.0761 & 5.35 & $18.2-22.9$ & 20.13 & 0.9946 & 4.94 \\
\hline $\mathrm{x}_{12}$ & $47.5-55.6$ & 52.00 & 1.7619 & 3.39 & $44.5-60.8$ & 52.11 & 2.5103 & 4.82 \\
\hline $\mathrm{x}_{13}$ & $34.9-50.1$ & 39.68 & 2.1481 & 5.41 & $30.7-43.3$ & 39.01 & 1.8931 & 4.85 \\
\hline $\mathrm{x}_{14}$ & $10.7-17.6$ & 13.38 & 1.1472 & 8.57 & $11.7-16.8$ & 13.95 & 1.0439 & 7.49 \\
\hline $\mathrm{x}_{15}$ & $9.6-14.9$ & 12.75 & 1.0235 & 8.03 & $10.4-15.1$ & 13.13 & 0.9650 & 4.35 \\
\hline $\mathrm{x}_{16}$ & $70.8-85.1$ & 78.32 & 2.0765 & 2.65 & $64.4-86.3$ & 78.42 & 2.4295 & 3.10 \\
\hline $\mathrm{X}_{17}$ & $6.7-10.3$ & 8.55 & 0.7029 & 8.22 & $6.7-14.6$ & 9.20 & 1.2501 & 13.59 \\
\hline $\mathrm{x}_{18}$ & $11.4-18.0$ & 15.11 & 1.2344 & 8.17 & $9.0-17.4$ & 15.02 & 1.3645 & 9.08 \\
\hline $\mathrm{x}_{19}$ & $7.9-13.1$ & 10.35 & 1.0628 & 10.26 & $7.6-12.0$ & 10.42 & 0.9465 & 9.08 \\
\hline $\mathrm{x}_{20}$ & $12.3-18.9$ & 15.55 & 1.3374 & 8.60 & $14.5-18.9$ & 16.60 & 1.0714 & 6.45 \\
\hline$x_{21}$ & $55.5-11.1$ & 7.90 & 0.6022 & 11.41 & $6.2-10.1$ & 8.15 & 0.7981 & 9.80 \\
\hline $\mathrm{x}_{22}$ & $9.4-14.5$ & 11.33 & 1.0275 & 9.07 & $9.5-14.2$ & 12.16 & 1.1216 & 9.23 \\
\hline$x_{23}$ & $9.8-15.6$ & 13.33 & 1.0285 & 7.72 & $12.9-19.9$ & 16.15 & 1.6930 & 10.49 \\
\hline$x_{24}$ & $11.2-19.5$ & 12.71 & 1.0890 & 8.57 & $10.2-15.7$ & 13.44 & 0.8971 & 6.67 \\
\hline$x_{25}$ & $26.5-51.9$ & 31.79 & 2.7354 & 8.61 & $25.9-38.3$ & 31.01 & 1.9597 & 6.32 \\
\hline $\mathrm{x}_{26}$ & $22.4-31.5$ & 27.05 & 1.7219 & 6.37 & $21.7-35.8$ & 26.63 & 2.0221 & 7.59 \\
\hline$x_{3}$ & $8.2-14.2$ & 11.24 & 0.7596 & 5.93 & $8.2-13.3$ & 10.49 & 1.0589 & 10.09 \\
\hline \multicolumn{9}{|c|}{ in $\%$ of head length } \\
\hline $\mathrm{x}_{4}$ & $30.1-42.9$ & 36.53 & 2.8469 & 7.79 & $31.3-42.9$ & 35.99 & 2.6478 & 7.36 \\
\hline $\mathrm{x}_{5}$ & $13.6-21.9$ & 17.80 & 1.8686 & 10.50 & $13.4-22.0$ & 17.96 & 1.9179 & 10.68 \\
\hline$x_{6}$ & $39.8-56,6$ & 48.82 & 3.0116 & 6,17 & $43.7-54.5$ & 48.75 & 2.3986 & 4.92 \\
\hline$x_{7}$ & $43.5-70.4$ & 58.25 & 6.1758 & 10.60 & $44.6-67.8$ & 56.92 & 5.2845 & 9.28 \\
\hline$x_{8}$ & $7.4-33.7$ & 17.35 & 3.2188 & 18.55 & $11.7-24.0$ & 17.88 & 1.9979 & 11.17 \\
\hline$x_{9}$ & $6.0-18.5$ & 11.21 & 2.2375 & 19.96 & $6.8-15.4$ & 11.00 & 2.0129 & 18.30 \\
\hline
\end{tabular}

\section{DISCUSSION}

Spined loach from Zegrzyński Dam Reservoir were of the same colour and appearance as those from River Wschodnia (Skóra 1966), a tributary of the Czarna Staszowska, the left-side tributary of the Vistula. As regards the parameters under study, the fish did not differ much from other spined loach populations (Tab. 5,6$)$.

The stock under study did not differ significantly from other stocks as regards the number of hard and soft rays in dorsal and anal fins. Earlier studies on spined loach revealed that the caudal fin had 16 soft rays, this parameter being quite different than in C. Sabanejewia aurata, which had 14 rays in this fin (Berg 1949; Banarescu 1964; Tortonese 1970; Opalatienko 1974). 
Comparison of plastic parameters of Cobitis taenia from Zegrzyński Dam Reservoir

Table 5 with the data from the literature

\begin{tabular}{|c|c|c|c|c|c|c|c|c|c|c|c|}
\hline \multirow{2}{*}{$\begin{array}{l}\text { Water body } \\
\text { Author } \\
\end{array}$} & \multirow[b]{2}{*}{$\mathrm{n}$} & \multirow{2}{*}{$\begin{array}{l}\text { Para- } \\
\text { meter }\end{array}$} & \multicolumn{5}{|c|}{ Soft ravs in fins } & \multirow{2}{*}{$\begin{array}{c}\text { sp. } \\
\text { branch }\end{array}$} & \multirow[t]{2}{*}{ vt. } & \multirow{2}{*}{$\begin{array}{l}\text { n.mac. } \\
\text { lateral. }\end{array}$} & \multirow{2}{*}{$\begin{array}{l}\text { n.mac. } \\
\text { dorsal. }\end{array}$} \\
\hline & & & $\mathrm{D}$ & $\mathrm{A}$ & $\mathrm{C}$ & $\mathrm{P}$ & $\bar{V}$ & & & & \\
\hline $\begin{array}{l}\text { Ukraina } \\
\text { Vladykov (1926) }\end{array}$ & & & $6-7$ & $5-6$ & $15-16$ & $6-8$ & $5-6$ & & & $12-20$ & \\
\hline $\begin{array}{l}\text { ZSSR } \\
\text { Berg (1949) }\end{array}$ & & & $6-7$ & $5-6$ & 16 & $5-6$ & $5-6$ & & $40-46$ & & \\
\hline $\begin{array}{l}\text { Nest Dwina } \\
\text { hukov (1965) }\end{array}$ & 24 & $\begin{array}{l}\text { Range } \\
\bar{x} \\
\text { S.D. }\end{array}$ & $\begin{array}{l}6-7 \\
6.67 \\
0.47\end{array}$ & $\begin{array}{l}5-6 \\
5.42 \\
0.49\end{array}$ & & \begin{tabular}{|l|}
$6-8$ \\
7.40 \\
0.71 \\
\end{tabular} & \begin{tabular}{|c|}
6 \\
6.00 \\
0.00
\end{tabular} & \begin{tabular}{|c|}
$9-12$ \\
10.88 \\
1.00
\end{tabular} & \begin{tabular}{|c|}
$41-44$ \\
42.62 \\
0.86
\end{tabular} & & \\
\hline $\begin{array}{l}\text { miepr } \\
\text { hukov (1965) }\end{array}$ & 25 & $\begin{array}{c}\text { Range } \\
\bar{x} \\
\text { S.D. }\end{array}$ & $\begin{array}{l}6-7 \\
6.84 \\
0.46 \\
\end{array}$ & \begin{tabular}{|l|}
$(4) 5$ \\
4.96 \\
0.19 \\
\end{tabular} & & $\begin{array}{l}6-8 \\
6.88 \\
0.70\end{array}$ & \begin{tabular}{|c|}
$5-6(7)$ \\
5.45 \\
0.55
\end{tabular} & & \begin{tabular}{|c|}
$38-42$ \\
40.08 \\
1.38
\end{tabular} & & \\
\hline $\begin{array}{l}\text { Wschodnia } \\
\text { Skóra (1965) }\end{array}$ & 83 & $\begin{array}{c}\text { Range } \\
\bar{x} \\
\text { S.D. }\end{array}$ & \begin{tabular}{|c|}
$6-7$ \\
6.71 \\
0.453 \\
\end{tabular} & \begin{tabular}{|c|}
$5-6$ \\
5.07 \\
0.259 \\
\end{tabular} & \begin{tabular}{|l|}
$15-16$ \\
15.61 \\
0.487
\end{tabular} & \begin{tabular}{|c|}
$6-9$ \\
7.18 \\
0.502
\end{tabular} & \begin{tabular}{|c|}
$5-7$ \\
5.43 \\
0.542 \\
\end{tabular} & $\begin{array}{l}11-12 \\
11.57 \\
0.496\end{array}$ & $\begin{array}{l}41-46 \\
43.51 \\
1.034\end{array}$ & \begin{tabular}{|c|}
$11-19$ \\
15.22 \\
1.68
\end{tabular} & $\begin{array}{l}13-25 \\
18.82 \\
2.859\end{array}$ \\
\hline $\begin{array}{l}\text { Dniestr } \\
\text { Opalatienko (1974) }\end{array}$ & 20 & $\begin{array}{c}\text { Range } \\
\bar{x}\end{array}$ & $\begin{array}{l}6-7 \\
6.85 \\
\end{array}$ & $\begin{array}{l}4.6 \\
5.0 \\
\end{array}$ & $\begin{array}{l}13-16 \\
13.85 \\
\end{array}$ & $\begin{array}{l}5-8 \\
6.40 \\
\end{array}$ & $\begin{array}{l}5.6 \\
5.20\end{array}$ & $11-15$ & \begin{tabular}{|l|}
$42-45$ \\
43.60 \\
\end{tabular} & & \\
\hline $\begin{array}{l}\text { Prut } \\
\text { Popa (1976) }\end{array}$ & & & $6-7$ & $5-6$ & $\mid 15-17$ & $7-8$ & 6 & & & & \\
\hline $\begin{array}{l}\text { Biebrza } \\
\text { Witkows }\end{array}$ & 49 & \begin{tabular}{|c|} 
Range \\
$\bar{x}$ \\
S.D. \\
\end{tabular} & $\begin{array}{l}5-7 \\
6.55 \\
0.54\end{array}$ & $\begin{array}{r}4-6 \\
5.00 \\
0.20 \\
\end{array}$ & & $\begin{array}{l}6-8 \\
7.36 \\
0.60\end{array}$ & \begin{tabular}{|l|}
$5-7$ \\
6.04 \\
0.28
\end{tabular} & & & $\begin{array}{l}12-22 \\
16.36 \\
2.51\end{array}$ & $\begin{array}{c}12-17 \\
13.97 \\
1.74\end{array}$ \\
\hline $\begin{array}{l}\text { Legińskie Lake } \\
\text { Białokoz (1986) }\end{array}$ & & & $\begin{array}{c}6-7 \\
7\end{array}$ & 5 & & $\begin{array}{c}6-7 \\
7\end{array}$ & 6 & $\begin{array}{c}9-10 \\
10\end{array}$ & $\begin{array}{c}41-44 \\
43\end{array}$ & & \\
\hline $\begin{array}{l}\text { Dgat Wielkie Lake } \\
\text { Białokoz (1986) }\end{array}$ & & & $\begin{array}{c}6-7 \\
7\end{array}$ & $\begin{array}{c}4-5 \\
5\end{array}$ & & 7 & $\begin{array}{c}5-6 \\
6\end{array}$ & $\begin{array}{c}8-11 \\
11\end{array}$ & $\begin{array}{c}42-46 \\
44\end{array}$ & & . \\
\hline $\begin{array}{l}\text { Zegrzyński Dam } \\
\text { Reservoir } \\
\text { author (1994) } \\
\end{array}$ & 139 & \begin{tabular}{|c|} 
Range \\
$\bar{x}$ \\
S.D. \\
\end{tabular} & \begin{tabular}{|c|}
$5-8$ \\
6.58 \\
0.5644 \\
\end{tabular} & \begin{tabular}{|c|}
$4-6$ \\
5.01 \\
0.3402 \\
\end{tabular} & \begin{tabular}{|l|}
$15-17$ \\
16.00 \\
0.350 \\
\end{tabular} & \begin{tabular}{|c|}
$5-8$ \\
6.11 \\
0.748
\end{tabular} & \begin{tabular}{|c|}
$5-7$ \\
5.66 \\
0.5458
\end{tabular} & \begin{tabular}{|c|}
$9-13$ \\
11.51 \\
0.873 \\
\end{tabular} & $\begin{array}{l}40-45 \\
43.05 \\
1.1389\end{array}$ & $\begin{array}{l}11-20 \\
14.81 \\
1.680\end{array}$ & $\begin{array}{l}13.26 \\
18.27 \\
1.315\end{array}$ \\
\hline
\end{tabular}

Compared to other populations, spined loach from Zegrzyński Dam Reservoir had less soft rays in the pectoral fin (Rubcov 1939; Shaposhnikova 1964). As regards number of soft rays in ventral fin, the discussed population did not differ from those in Wschodnia River, Dnieper River, and upper Dniestr River ( $\mathrm{P}>0.05$ ) (Zhukov 1965; Skóra 1966; Opalatienko 1974), although it differed significantly from those in Biebrza and Zachodnia Dwina rivers $(\mathrm{P}<0.05)$ (Tab. 5). Number of soft rays in this fin is characterized by high coefficient of variability (Skóra 1966, this paper).

The available data (Tab. 5) revealed that spined loach from Zegrzyński Reservoir was characterized by the same number of gill rakers, vertebrae and number of spots at the sides of the body as the fish in Wschodnia River (Skóra 1966, P > 0.05).

Pharyngeal teeth are one-row. According to Staff (1950) spined loach has 8 to 10 teeth on each side. The same number was given by Skóra (1966) for samples from Wschodnia River. Investigated fish had 8 to 11 pharyngeal teeth. 
Body proportions of the fish under study were similar to those in the Biebrza River (Witkowski 1984). Relative values of: eye diameter, head height, distance between eyes, pre- and postdorsal distance, caudal part, height of dorsal and anal fin, $\mathrm{V}$ - A distance, and $\mathrm{P}-\mathrm{V}$ distance did not differ significantly, $\mathrm{P}>0.05$ (Tab. 6). Fish from Zegrzyński Reservoir differed from those in Odra River (Frankiewicz 1985) with respect to a number of parameters except the predorsal distance, the lowest body height, length of $\mathrm{V}$ fins, and $\mathrm{P}-\mathrm{V}$ distance. They possessed different body proportions than the fish from the Moscov River $(\mathrm{P}<0.05)$.

Analysis of the mean values of biometric parameters in spined loach revealed that the fish were characterized by slightly longer head in relation to body length and different proportions of body height $(\mathrm{P}<0.05$, due to sexual dimorphism of this parameter) than spined loach from other populations. It should be noted that the samples did not contain juvenile fish, smaller than $50 \mathrm{~mm}$ 1.c., while this study showed that body proportion in spined loach changed with fish growth.

So far the described differences between males and females were the length of pectoral fins (Berg 1949; Vasileva 1984, 1988; Frankiewicz 1985) and body length: bigger in females (Tortonese 1970; Robotham 1981; Marconato and Rasotto 1989).

Attention should be given to the differences in paired fin length and body height of a related species Cobitis Sabanejewia aurata (Rolik 1960; Misik 1958). Males and females of this species also differ with respect to dorsal and anal fin length and body proportion.

\section{CONCLUSIONS}

1. Spined loach, Cobitis taenia from Zegrzyński Dam Reservoir were characterized by the following features: all fish had one black spot at the base of caudal fin, fin formulas were: D II, III 7 (6); C I 14 I; A II, III 5; V I 6 (5); P I 6 (7); number of gill rakers 11 (12); pharyngeal teeth $11: 11,(10: 11),(9: 10),(10: 10)$.

2. Males were characterized by higher body than females, longer pectoral and ventral fins, higher dorsal and anal fin. As the fish grew in length the postdorsal distance increased, dorsal fin moved closer to head, preanal distance decreased, lateral head length shortened.

3. Body proportions were similar to those obseved in spined loach from the Biebrza River (Witkowski 1984). All calculable parameters were close to those given for spined loach from the Wschodnia (Skóra 1966) and Biebrza rivers.

4. Apart from the differences in biometric parameters, spined loach males were distinguishable from females because they possessed a bony structure i.e. Canestrini's lamina on the second ray of pectoral fins. Shape of this organ is a systematic feature of the species (Kim and Jeong 1988; Vasileva 1988; Vasilev et al. 1989). 
Comparison of biometric parameters of Cobitis taenia from Zegrzyniski Dam Reservoir with the data from the literature

Table 6

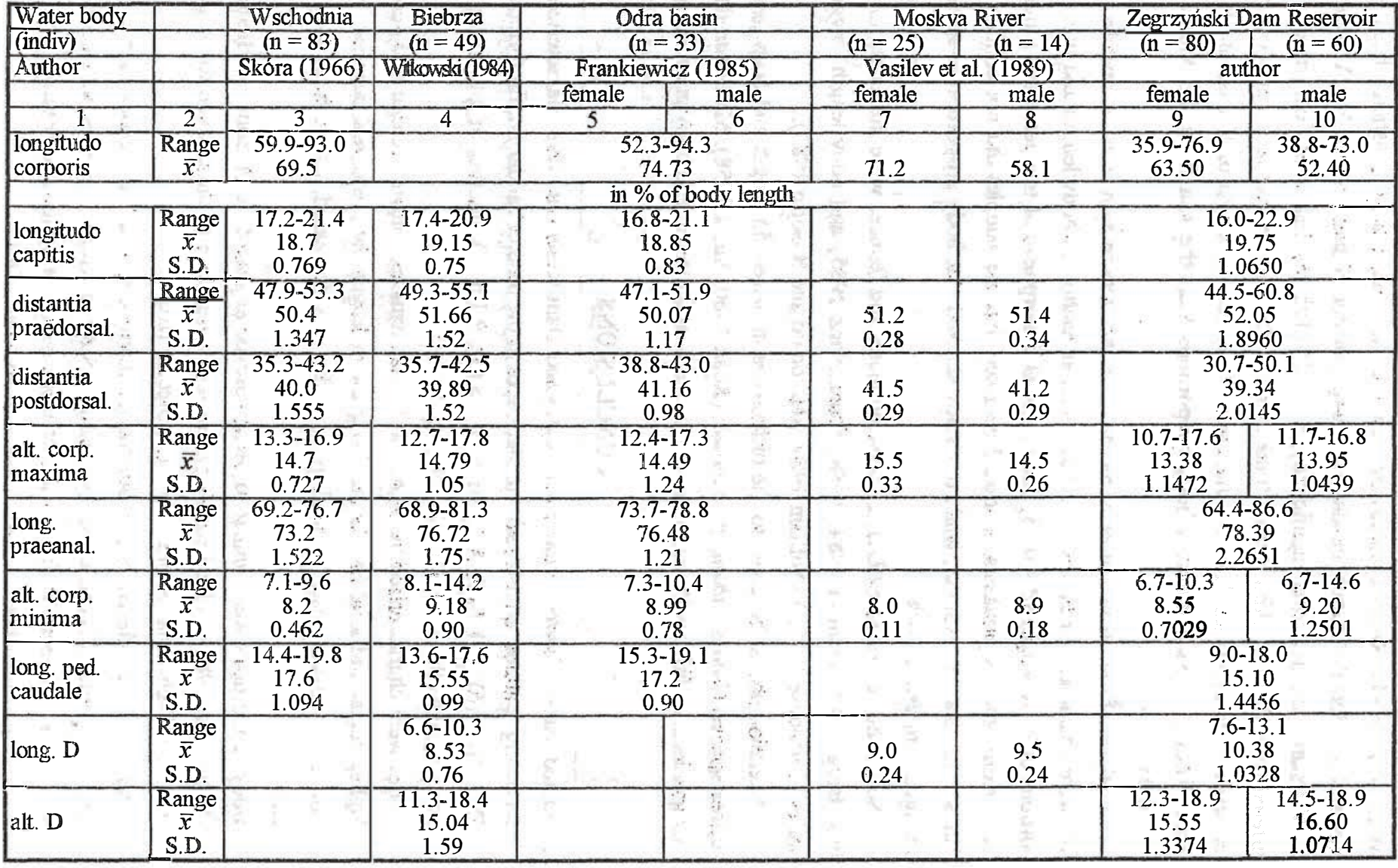


contd. Table 6

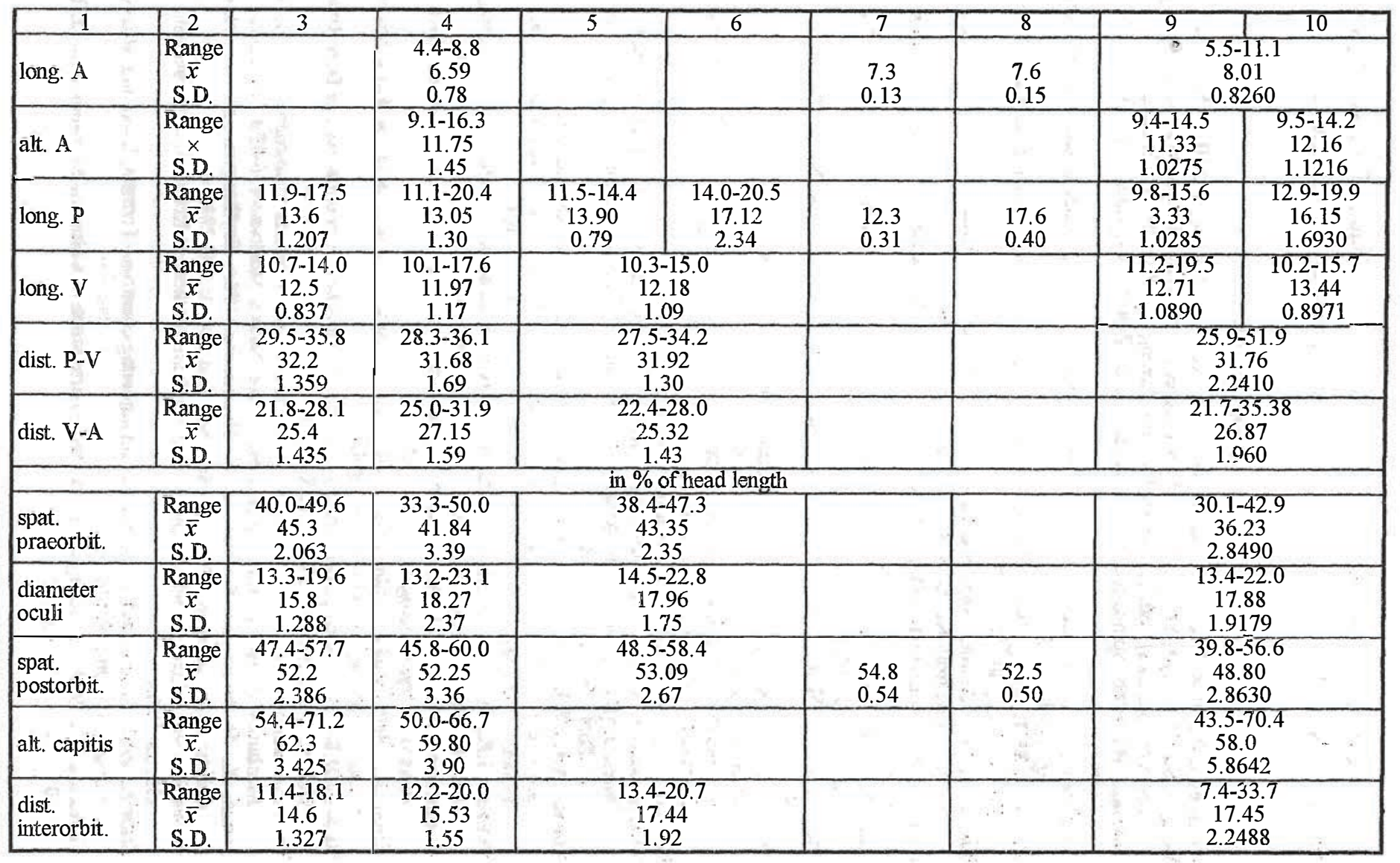




\section{ACKNOWLEDGEMENT}

I would like to express my sincere thanks to Dr Janusz Terlecki, Department of Zoology, Olsztyn University of Agriculture and Technology, for valuable help.

\section{REFERENCES}

Banarescu P., 1964: Pisces (Osteichthyes). Fauna Rep. Pop. Romme, V-XIII, 1: 519-546.

Berg L. S., 1949: Ryby presnych vod SSSR i sopredelnych stran. [Freshwater fish of the USSR and adjacent countries]. Izd. AN SSSR,Moscow, Leningrad : 889-893. (In Russian).

Bialokoz W., 1986: Spined loach (Cobitis taenia). In: Polish Freshwater Fish, PWN : 321-324. (In Polish).

Frankiewicz $\mathbb{P}$., 1985: Golden loach, Cobitis aurata (Fil.) in the drainage basin of the Odra River. Przegl. Zool. 3 : 331-337. (In Polish).

Kim I.S., M.T. Jeong, 1987: Cobitis sinensis (Pisces, Cobitidae) from the Nektong River, Korea. Kor. J. Zool., 30 (1) : 71-78.

Kim I.S., M.T. Jeong, 1988: Seasonal Variation of the Color Pattern in the Cobitid Fish Cobitis taenia lutheri from Korea. Kor. J. Ecology, 11, $2: 77-82$.

Lodi E., 1979: Variability of the Canestrini's organ in Cobitis taenia L. Riv. It. Piscic. Ittiop., 14, 3 81-88.

Lodi $\mathbb{E}_{.9}$ 1980: Supernumerary Canestrini's organs in Cobitis taenia bilineata Canestrini. Riv. It. Piscic. Ittiop, 15, $4: 97-102$.

Marconato A., M.B. Rasotto, 1989: The biology of a population of spined loach, Cobitis taenia L. Boll. Zool., 56: 73- 80.

Misik V., 1958: K vyskutu a biometrike plza horsekeho balkanskeho (Cobitis aurata) (Filippi 1865) balcanica Karaman, 1922 natio montana (?) (Vladykov 1925) z rirky Kysuce. [An occurrence and biometric of Cobitis aurata (Filippi, 1865) balcanica Karaman, 1922 nation montana (?) Vladykov, 1925 from River Kysuca]. Biol., 13 : 810-832. (In Czech).

Nellson J.S., 1984: Fishes of the World. A Wiley-Interscience Pub1. USA, pp. 523 : 126-127.

Opalatienko L.K., 1974: K morfobiologicheskoj kharakterystike vjunovykh (Cobitidae) Verkhnevo Dniestra. [Morphobiological characteristic of loaches (Cobitidae) from the Upper Dnestr River]. Vest. Zool., 6:12-36. (In Russian).

Osinov A.G., E.D. Vasileva, V.P.Vasilev, 1983: Gibrydnoje proiskhozhdenie odnopoloj triploidnoj formy roda Cobitis (Cobitidae, Pisces). [The hybrid origin of the triploid form in genus Cobitis (Pisces, Cobitidae)]. Dokl. AN SSSR, 272 : 716-18. (In Russian).

Pravdin I.F., 1931: Rukovodstvo po izucheniju ryb. [Handbook of ichthyological methods]. Siel. khoz: Kolkh., Moskva-Leningrad, pp. 375. (In Russian).

Robotham P.W.J., 1981: Age, growth and reproduction of a population of spined loach, Cobitis taenia (L.). Hydrobiologia, 85 : 129-136.

Rolik H., 1960: Cobitis aurata (Filippi 1865) golden loach, new species in the Baltic Sea drainage. Fragm. Faun., 8, $26: 411-420$. (In Polish).

Rubcov D.B., 1939: Shchipovki verkhnevo Dona. [The loaches from upper part of Don River]. Biul. Biol. St. Voroniezh, 1: 65-71. (In Russian).

Shaposhnikova G.H.o, 1964: Biologia i raspredelenie ryb v rekach uralskogo typa. [Biology and distribution of fish in Ural type of rivers]. Izdat. Nauka, Moskva : 136-139. (In Russian).

Sezaki $\mathbf{K}$. H. Kobayasi, S. Watabe, $\mathbf{K}$. Hashimoto, 1985: Erythrocyte size and poliploidy of Cobitid fishes in Japan. Bull. Jap. Soc. Sci. Fish., 51, 5: 777-781.

Skóra S., 1966: Spined loach (Cobitis taenia L.) from Wschodnia River. Acta Hydrobiol., 8 : 425 435. (In Polish).

Staff F., 1950: Freshwater fish in Poland and adjoining countries. Trzaska, Evert and Michalski Ed., Warszawa : 200-204. (In Polish).

Tortonese $\mathbb{E}_{.}$, 1970: Osteichthyes (Pesci Ossei) parte prima in Calderini ed. Fauna d'Italia, Bologna, 10: 284-295. (In Italian). 
Ueno K., Y. Ojima, 1976: Diploid-tetraploid complexes in the genus Cobitis., Proc. Jap. Acad., B $52:$ 446-449.

Vasilev V.P., E.D. Vasileva, A.G. Osinov, 1989: Evolution of a diploid-triploid-tetraploid complex in fishes of the genus Cobitis (Pisces, Cobitidae). New York State Museum, Alabany, Bull. 466 : 153-169.

Vasilev V.P., E.D. Vasileva, A.G. Osinov, 1990: K problemie setcatovo vidoobrazovania u pozvonochnych: diploidno-triploidno-tetraploidnyj kompleks v rode Cobitis (Cobitidae). III. Proiskhozhdenie triploidnoj formy. [Reticulate evolution in vertebrates: the diploid-triploid-tetraploid complex in genus Cobitis (Pisces, Cobitidae) III. Origin of the triploid form]. Vopr. Ikhtiol. 30, 4 : 543-550. (In Russian).

Vasileva E.D., 1984: Sravnitelnyj morfologicheskij analiz dvukh populacij shchipovok (Rod Cobitis, Cobitidae), otlichajushchikhsja chislom pjaten u osnovanija khvostovogo plavnika. [Comparative morphological analysis of two populations of spined loaches (genus Cobitis) differing by a number of spots at the base of a caudal fin]. Vopr. Ikhtiol., 24 : 45-53. (In Russian).

Vasileva E.D., 1988: Preopisanie, morfo-ekologicheska kharakteristika i rasprastranenie Cobitis granoei (Teleostei, Cobitidae). [The redescription, morphological properties, ecology and distribution of Cobitis granoei Rendahl, 1935 (Teleostei, Cobitidae)]. Zool. zhum., 67 : 1025-1037. (In Russian).

Witkowski A., 1984: An analysis of the ichthyofauna of the Biebrza River basin. Acta Univ. Wratisl., Prace Zool. 14 : 70-73. (In Polish).

Zuk B., 1989: An applied biometry. PWN, Warszawa : 37-50. (In Polish).

Zhukov P. I., 1965: Ryby Belorussi. [Fishes of Belorussia]. Nauka i Technika, Minsk : 330-333. (In Russian).

\section{Alicja $B O R O N$}

\section{CECHY MERYSTYCZNE I BIOMETRYCZNE KOZY, COBITIS TAENIA (L.) (CYPRINI- FORMES, COBITIDAE) Z ZEGRZYŃSKIEGO ZBIORNIKA ZAPOROWEGO}

\section{STRESZCZENIE}

Celem pracy była analiza cech merystycznych i biometrycznych kozy - Cobitis taenia z Zegrzyńskiego Zbiomika Zaporowego, znalezienie różnic w proporcjach ciała samic i samców, porównanie ơrzymanych wyników $\mathrm{z}$ rezultatami zamieszczonymi w piśmiennictwie.

Kozy reprezentujące populację zamieszkującą wymieniony zbiornik charakteryzowały się następującymi cechami: wszystkie posiadaly jedną czarną plamkę u podstawy płetwy ogonowej, wzór płetw można zapisać: D II, III 7 (6); C I 14 I; A II, III 5; V I 6 (5); P I 6(7); ilość wyrostków filtracyjnych 11 (12); zebby gardłowe jednoszeregowe 11:11, (10:11), (9:10), (10:10).

Stwierdzono występowanie różnic $w$ wartościach cech biometrycznych pomiędzy płciami; samce w porównaniu z samicami miały wyższe ciało, dłuższe płetwy piersiowe i brzuszne, wyższa płetwe grzbietową i odbytową.

Analiza zależności zachodzących pomiędzy badanymi cechami i długością ciała lub głowy wykazała, że proporcje ciała zmieniają się wraz ze zwięsszaniem się rozmiarów ryb. W miarę wzrostu dhugości ciała samic i samców wzrasta odległość zagrzbietowa, płetwa grzbietowa przesuwa się bliżej głowy, maleje odległość przedanalna, skróceniu ulega długość boczna głowy.

Poza różnicami $\mathrm{w}$ wartościach cech biometrycznych samce kozy sa dobrze odróżnialne od samic ponieważ na drugim promieniu płetwy piersiowej mają kostną narośl, organ Canestrini, w kształcie owalnej blaszki. Kształt płetwy piersiowej samców jest też charakterystyczny, ponieważ drugi promień jest dłuższy od pozostałych. U samic trzeci promień jest najdłuższy, co sprawia, że płetwa ma inny kształt. 
Proporcjami ciała omawiane ryby zbliżone były do kóz z Biebrzy (Witkowski 1984). Pod względem cech policzalnych podobne do ryb z rzeki Wschodniej (Skóra 1966) i Biebrzy (Witkowski 1984).

Author's address:

Received: 1993.09 .10

Ph.D. Alicja Boroń

Department of Zoology

University of Agriculture and Technology

10-957 Olsztyn-Kortowo, Poland 